\title{
Factors that Influence the Work Interest of Prospective Undergraduate Education in Industry
}

\author{
Agung Widiyanto1*, Putu Sudira ${ }^{2}$, Rabiman Rabiman ${ }^{3}$, Yayan Adrianova Eka Tuah ${ }^{4}$ iD \\ ${ }^{1,2}$ Department of Technological and Vocational Education, Yogyakarta State University, Indonesia \\ *Corresponding author: agungwidiyantoro.2019@student.uny.ac.id
}

\begin{abstract}
The job market has a strong influence on the preferences of new graduates. One of these phenomena occurred at the Universitas Sarjanawiyata Tamansiswa Yogyakarta. Although the field occupied in this educational institution is pedagogic science, many graduates from this university are indifferent to the scientific family. This study aims to analyze the effect of work interest in Mechanical Engineering Education (MEE) industrial students on income, attention, willingness, family environment, and community environment. This study uses the ex-post-facto method. This study involved 82 students. The sampling technique used is simple random sampling with a questionnaire to collect data. The results showed that: (1) income expectations, attention, willingness, family environment, and community environment all had a positive and significant effect on interest in working in the industry; (2) income expectations have a positive and significant effect on job interest in the industry; (3) Attention has a positive and significant effect on interest in working in the industry, (4) willingness has a positive and significant effect on interest in working in the industry, (5) family environment has a positive and significant effect on interest in working in the industry, and (6) community environment has an effect positive and significant to work interest in the industry.
\end{abstract}

Keywords: Community Environment, Family Environment, Income Expectation, Willingness

$\begin{array}{ll}\text { History: } & \text { Publisher: Undiksha Press } \\ \text { Received : June 25, } 2021 & \text { Licensed: This work is licensed under } \\ \text { Revised : June 30, } 2021 & \text { a Creative Commons Attribution 3.0 License } \\ \text { Accepted : September 23, } 2021 & \text { Cc } \\ \text { Published : October 25, } 2021 & \text { O) }\end{array}$

\section{INTRODUCTION}

The industrial sector has an essential role in encouraging economic growth in Indonesia. The industrial sector is one of the sectors that absorb workers in Indonesia. The number of industrial units in an area and the minimum wage is one of the supporters (Muhtamil 2017; Rochmani, Purwaningsih, and Suryantoro 2017; Saefurrahman, Suryanto, and Ekawulandarisiregar 2017). Quality educational institutions are needed to meet the demand from the industrial sector for a quality workforce. Educational institutions play a role in providing human resources and sometimes collaborating with industry to create links and matches (Ashari, Abdal, and Setialaksana 2021; Disas 2018; Cahyanti, Indriayu, \& Sudarmo 2018; Rybnicek and Königsgruber 2019). One of the educational institutions in Indonesia that play a role in providing a workforce is the Sarjanawiyata Tamansiswa university Yogyakarta.

Students of the Mechanical Engineering Education Study Program, Sarjanawiyata Tamansiswa university Yogyakarta, have a strong interest in entering the industrial world. Students choose to work in industry rather than become educators, as evidenced by interviews with their (teachers). Working as a teacher with the status of a Civil Servant in a private SMK is quite difficult because the salary is small, and the career path of a private SMK teacher is not clear, so most students prefer to work in the industry. The percentage of students interested in working in the industrial sector is 48 percent, while the proportion interested in becoming teachers is $32 \%$ and other interests are $20 \%$. is relatively high. The factors that influence interest are divided into two categories.

Intrinsic factors drive interest, such as the need for income, personal values, selfconcept, self-esteem, perceptions, and feelings (Buil et al., 2019; Liu, 2020; Mekler et al., 
2017). Pleasure and extrinsic factors include the family environment, community environment, job opportunities, and education (Annetta et al., 2013; Liu, 2020). In addition, interest analysis can be carried out on the desire to know or have an object of interest, a preferred object or activity, the type of activity to achieve the desired thing, efforts to realize a desire, a sense of pleasure in something interesting for him (Suttikun et al., 2018; Zain, 2017). Interest and passion in work will be positively correlated with the energy that will be released by the individual (Indriasari \& Setyorini, 2018; Vallerand, 2015). In psychology, passion for work will lead to satisfaction by an individual. Passion in work is also related to appreciation by the company to workers, usually in the form of salary (Hanna, Kee, \& Robertson 2017; Indriasari \& Setyorini 2018; Purba and Ananta 2018).

Income is also one factor that influences individuals to decide what field of work they will pursue. Income affects the level of worker satisfaction and job selection (Bensidoun \& Trancart 2018; Bercu \& Onofrei 2017; Tampu \& Cochina 2015; Davidescu et al. 2020). The industry is one sector that offers many incentives to individuals, especially income. The Industrial Sector offers various benefits by companies, both salary, health insurance, and other benefits (StalmaĹ ${ }^{`}$ ekovA $\breve{A}^{`}$ et al., 2017). Several studies also show that the benefits to workers offered by industrial companies are an attraction for the new workforce. This issue is not only in developing countries but also in developed countries. The new workforce (26-30) has a physical condition that is still strong and effective so that they tend to have the satisfaction of entering the automotive industry (Unuvar et al., 2016).

Although it offers an excellent income to increase the well-being of an individual, working in the industrial sector also has its downsides. One of the reasons for working in the industrial sector is the safety factor (Asilah \& Yuantari 2020; Ramdan and Handoko 2016; Rizka Pisceliya and Mindayani 2018). In addition to the security factor that does not guarantee that the industry in Indonesia also pays less attention to the welfare of work through outsourcing programs, this system hinders old age protection for workers (Sudiarawan 2017; Husin 2021; Prabhaputra 2019; Putri et al., 2015; Sukamto 2019). Therefore, working in the industry is not always profitable because sometimes there are losses there. Based on the potential debate and problems in the Industrial sector, there is a new student workforce. Thus, the emergence of this debate has become a unique phenomenon to be seen in the case of students of the Mechanical Engineering Education Study Program at Sarjanawiyata Tamansiswa university Yogyakarta. This article focuses on finding out the cause of the desire of Mechanical Engineering Education students at Sarjanawiyata Tamansiswa university Yogyakarta to work in the industry influenced by income expectations, attention, willingness, environment.

\section{METHODS}

The type of research used is the type of ex post facto. Ex-post facto research is a method that is widely used in situations faced by many educational researchers. The ex post facto method has been proven to have helped conduct cause and effect research (Sujarwanta, Noor, \& Sulistiani 2017; Modebe et al., 2017; Khaerunnisa 2017). Ex post facto research reveals facts based on symptom measurements that occurred in respondents and before this research was conducted. The data uses in this study is primary data. Primary data is original and unique data collected by researchers from a source, and it is obtained from the field (Ajayi, 2017). Preliminary data is obtained from Mechanical Engineering Education Study Program, Faculty of Teacher Training and Education, Sarjanawiyata Tamansiswa university. The variables used in this study consisted of the dependent variable and the independent variable. The population in this study were undergraduate students of the Mechanical Engineering Education Study Program batch of 2017, as many as 82 students. This study 
uses a simple random sampling technique (simple random sampling), and the data collection technique in this study uses a questionnaire. The questionnaire contains the independent variable $(\mathrm{X})$ and the dependent variable $(\mathrm{Y})$. The independent variable $(\mathrm{X})$ is divided into Income Expectations (X1), Attention (X2), Willingness (X3), Family Environment (X4), and Community Environment (X5), while the dependent variable (Y) is interested in working in the industry.

Every variable has indicators that affect the variable. High income and unlimited income indicators affect Income Expectations (X1). Interested and intensive attention indicators affect Attention (X2). Practice effort, effort to know, and possession of good perception of work affect willingness (X3). Socio-economic conditions and the way parents educate students affect Family Environment (X4). Friends and student activities in the community affect Community Environment (X5). The desire to know or have an object of interest, objects, or activities that he likes; the types of activities to achieve the things he likes and the effort to realize the desire, a sense of pleasure towards something he is interested in; affect the interest working in the industry. Respondents were given survey questions measured using a Likert scale, namely to express the feelings of respondents by choosing five alternative answers from 1 (SD) to 5 (SA) to find out the most dominant indicator of each variable. The data analysis technique used multiple regression analysis. Hypothesis testing using partial correlation test. Hypothesis 1 was tested using multiple regression analysis, whereas hypotheses $2,3,4,5$, and 6 were tested using a partial correlation test. Each independent variable's Relative Contribution (RC) and Effective Contribution (EC) were also determined.

\section{RESULTS AND DISCUSSION}

\section{Results}

The data described in this study describes the research results of each variable, namely income expectations, attention, willingness, family environment, and community environment as independent variables and working interest in the industry for Mechanical Engineering Education Study Program students Sarjanawiyata Tamansiswa University as the dependent variable. The data for each variable is categorized into very high, high, medium, low, and deficient. It is classifying using mean score obtained by 'how to add high and low scores then divide by two, for the mean is obtained by increasing the high score and low score then dividing by two, and Standard deviation score that can be obtained by reducing the high score by the low score and then dividing by two. The descriptive analysis of the income expectation variable revealed that 28 students were in the very high category, with a relative frequency of $34.15 \%$, and 29 students were in a low category, with a relative frequency of $35.37 \%$. The scoring category above showed that ten students were in the very high category with a relative frequency of $12.20 \%$, while 36 students were in the very low category with a relative frequency of $43.90 \%$. In comparison to the other categories, the low category had the most presentations.

Based on the above score categories, 16 students were included in the high category with a relative frequency of $19.52 \%$. Five students were included in the low category with a relative frequency of $6.10 \%$. Based on the results of data analysis, it can be assumed that 11 students were in the high category with a relative frequency of $13.41 \%$, while 47 students were in the very low category with a relative frequency of $57.32 \%$. Based on the results of data analysis, 25 students were in the high category with a relative frequency of $30.49 \%$, while 29 students were in the low category with a relative frequency of $35.37 \% .24$ students were classified as high, with a relative frequency of $29.27 \%$, and 11 students were classified as low, with a relative frequency of $13.41 \%$. The price of $\mathrm{KS}-\mathrm{Z}$ is known to be 0.082 , with a 
p-value of 0.200 greater than 0.05 . Because the probability value is greater than the $5 \%$ significance level, it is assumed that all data are typically distributed. It was discovered that a VIF value $<10$ indicates that there is no multicollinearity and thus that the multicollinearity test is met.

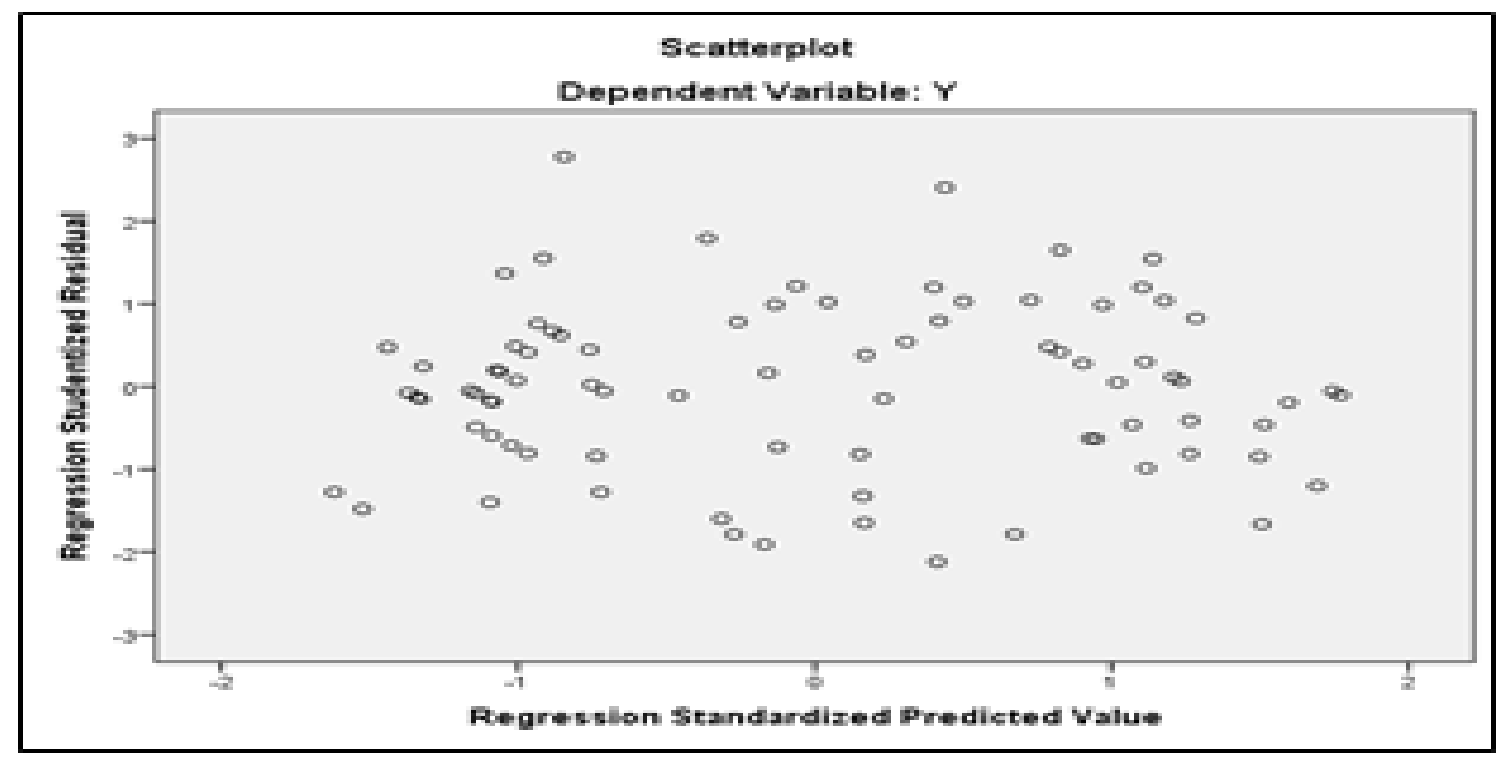

Figure 1. Result of Heteroscedasticity Test

The scatterplot image above shows that the points are spread randomly, it does not form a clear specific pattern, and it is applied both above and below the number 0 on the $\mathrm{Y}$-axis. It is possible to conclude that the independent variables discussed above do not demonstrate heteroscedasticity. The first hypothesis test employs a multiple regression test with five predictors. $\mathrm{Y}=0.024+0.271 \mathrm{X} 1+0.441 \mathrm{X} 2+0.257 \mathrm{X} 3+0.197 \mathrm{X} 4+0.089 \mathrm{X} 5$ is the multiple regression equation. The determinant coefficient $\left(\mathrm{R}^{2}\right)$ is 0.760 , indicating that the magnitude of the influence between the independent and dependent variables is $76 \%$, with the remaining $24 \%$ influenced by factors not discussed in this study. The F test with ANOVA yielded the value Freg reg $=52.203$ with a p-value (significance) of 0.000 . Based on these findings, the significance value is $0.000<0.05(\mathrm{p}<5 \%)$, indicating that the hypothesis is accepted. The amount of Relative Contribution (RC) and Effective Contribution (EC) of each variable depending on the variable. The magnitude of SE and SR can be seen in the table below. The amount of Relative Contribution (RC) and Effective Contribution (EC) of each independent variable to the dependent variable are known. The correlation coefficient $\mathrm{r}_{\text {count }}$ is 0.395 , with a $0.000<0.05$ level of significance. Because the significance level of 0.000 is less than 0.05 , it can be concluded that there is a positive relationship between income expectations and working interest in the industry.

With a significance level of $0.000<0.05$, the correlation coefficient $r_{\text {count }}$ is 0.480 . Because the significance level of 0.000 is less than 0.05, it can be concluded that there is a positive relationship between attention and working interest in the industry. With a significance level of $0.000<0.05$, the correlation coefficient $r_{\text {count }}$ is 0.480 . Because the significance level of 0.000 is less than 0.05 , it can be concluded that there is a positive relationship between attention and working interest in the industry. The correlation coefficient $r_{\text {count }}$ value is 0.379 , with a significance level of $0.001<0.05$. Because the significance value is 0.001 less than the 0.05 significance level, it can be concluded that the family environment has a positive influence on working interest in the industry. The correlation coefficient $r_{\text {count }}=0.276$, with a level of significance of $0.015<0.05$. Because the 
significance value of 0.015 is less than the 0.05 significance level, it can be concluded that the community environment has a positive influence on working interest in the industry.

\section{Discussion}

The significance value is $0.000<0.05$, it is possible to conclude that there is a positive and significant relationship between income expectations, attention, willingness, family environment, and community environment as the independent variables and working interest in the industry as the dependent variable. If the expected value of income, attention, willingness, family environment, and community environment is high, it is the expected value of the working interest in the industry. The determinant coefficient $\left(R^{2}\right)$ is 0.760 , indicating that the magnitude of the influence between the independent and dependent variables is $76 \%$, with the remaining $24 \%$ influenced by factors not discussed in this study.These results indicate that interest in working in the industry is one of the internal factors in students (Abulhassn \& Roberts, 2021; Chan, 2021). Which is shown through students' interest in working in one of the industrial fields according to their characteristics (Abbas \& Sagsan, 2020; Shaalan, 2019). The will is the will directed toward specific life goals and is regulated by rational considerations (Butler \& Shibaz, 2014; Ferrer-Estévez \& Chalmeta, 2021). So there is reasoned wisdom and insight in that will and control and approval from the heart of personality. As a result, instinct, reflex, automatism, habit, lust, desire, inclination, and lust are higher than will.

Someone who works in the industry wants a higher income than working in a nonindustrial job (Crawley et al., 2019; Suttikun et al., 2018). The higher the expected income through working in the industry, the higher the industry's interest (Gohae, 2020; Rahmah \& Muslim, 2019). With the hope of getting a large income, it will encourage students' interest to work in the industry. Someone may be interested in becoming an entrepreneur or working in the industry since he can earn more if he succeeds more than a teacher (Abbas \& Sagsan, 2020; Chan, 2021). Income expectations are expectations to earn larger earnings, and that increased income expectations will promote student interest in entrepreneurship (Blesia et al., 2021; Sakthi \& Moshi, 2021). Most people would choose any occupation to earn as much money. In other words, they will find a job that will offer a high salary or more benefits. Attention is crucial for properly participating in activities, and it will also affect students' interest in their work (Ives et al., 2020; Waruwu, 2020). Attention in work is heightened soul activity in which the soul is entirely concentrated on an item (object/thing) or a group of things. Attention is a reaction of the organism and consciousness that results in increased activity, concentrated power, and limited awareness of a single object (Crowne et al., 2020; Stellmacher et al., 2020). Someone interested in a particular job will pay great attention to that job. Thus, a student interested in working in the industry will try hard to get the desired job and pay special attention to the expected job. A strong desire to work in the industry will provide a strong impetus for students to know more about the job. This strong desire will also affect their interest in working in the industry (Ives et al., 2020; Stellmacher et al., 2020).

The choice of a profession cannot be separated from the role of the family. The family is where the main activity of one's life occurs so that the family becomes the determinant in one's development (Indra et al., 2019). The family environment is also the first and foremost environment that influences the development and behavior of students. Indirectly, parents can influence their children in choosing a job. With the support of the family, they can encourage their children to become workers in the industry. There is a significant relationship between family influence and career choice. The involvement of parents in their children's everyday life increases self-confidence when choosing the best career among the many appealing career options and also shows that there is a good and significant association between the home environment and working interest in the industry (Afzal Humayon et al., 2018). The 
student also chooses to work in the industry because of their family situation, past experiences, and salary (Sundar, 2019).

The data calculations in this study are proven in the case of mechanical engineering education students' class of 2017 at Sarjanawiyata Tamansiswa university in Yogyakarta. So the results from this study may not be the same as mechanical engineering students at other universities in Indonesia due to differences in characteristics, culture, and the surrounding environment. For this reason, further research should be carried out on cases in other locations. So, the generalization in this study is said to be an imperfect generalization.

\section{CONCLUSION}

According to the findings, income expectations, attention, willingness, family environment, and community environment positively influenced the industry's working interest. Income expectations have a significant positive influence on working interest in the industry. Attention has a positive and significant influence on working interest in the industry. Willingness has a significant influence on working interest in the industry. The family environment has a positive and significant influence on the working interest in the industry. The community environment has a significant and positive influence on working interest in the industry.

\section{REFERENCES}

Abbas, J., \& Sagsan, M. (2020). Identification of key employability attributes and evaluation of university graduates' performance: Instrument development and validation. Higher Education, Skills and Work-Based Learning, 10(3), 449-466. https://doi.org/10.1108/heswbl-06-2019-0075

Abulhassn, A., \& Roberts, E. P. L. (2021). Exploring the impact of an NSERC Create program on job readiness among science and engineering graduate students and postdoctoral fellows. Education for Chemical Engineers, 36. https://doi.org/10.1016/j.ece.2021.06.002

Afzal Humayon, A., Raza, S., Aamir Khan, R., \& ul ain Ansari, N. (2018). Effect of Family Influence, Personal Interest and Economic Considerations on Career Choice amongst Undergraduate Students in Higher Educational Institutions of Vehari, Pakistan. International Journal of Organizational Leadership, 7(2), 129-142. https://doi.org/10.33844/ijol.2018.60333

Ajayi, V. O. (2017). Primary Sources of Data and Secondary Sources of Data. September, 16. http://dx.doi.org/10.13140/RG.2.2.24292.68481

Annetta, L. A., Frazier, W. M., Folta, E., Holmes, S., Lamb, R., \& Cheng, M.-T. (2013). Science teacher efficacy and extrinsic factors toward professional development using video games in a design-based research model: The next generation of STEM learning. Journal of Science Education and Technology, 22(1), 47-61. https://link.springer.com/article/10.1007/s10956-012-9375-y

Ashari, H., Abdal, N. M., \& Setialaksana, W. (2021). Pengembangan Model Link and Match Melalui Praktek Kerja Industri (Prakerin) Jurusan Teknik Tenaga Listrik. Jurnal Media Elektrik, 18(1), 8-13. https://doi.org/10.26858/metrik.v18i1.19407

Asilah, N., \& Yuantari, M. C. (2020). Analisis Faktor Kejadian Kecelakaan Kerja pada Pekerja Industri Tahu. Penelitian Dan Pengembangan Kesehatan Masyarakat Indonesia, 1(1), $1-10$. https://journal.unnes.ac.id/sju/index.php/jppkmi/article/view/41434

Bensidoun, I., \& Trancart, D. (2018). Career choices and the gender pay gap: The role of 
work preferences and attitudes. Population, 73(1), 35-62. https://doi.org/htt10.3917/popu.1801.0035.

Bercu, A.-M., \& Onofrei, M. (2017). The Empirical Research on Civil Servants' Motivation: Evidence from Romania. Managing Global Transitions, 15(4), 399-417. https://doi.org/10.26493/1854-6935.15.399-417

Blesia, J. U., Iek, M., Ratang, W., \& Hutajulu, H. (2021). Developing an Entrepreneurship Model to Increase Students' Entrepreneurial Skills: an Action Research Project in a Higher Education Institution in Indonesia. Systemic Practice and Action Research, 34(1), 53-70. https://doi.org/10.1007/s11213-019-09506-8

Buil, I., Catalán, S., \& Martínez, E. (2019). The International Journal of Encouraging intrinsic motivation in management training: The use of business simulation games. The International Journal of Management Education, 17(2), 162-171. https://doi.org/10.1016/j.ijme.2019.02.002

Butler, R., \& Shibaz, L. (2014). Striving to connect and striving to learn: Influences of relational and mastery goals for teaching on teacher behaviors and student interest and help seeking. International Journal of Educational Researc, 65. https://doi.org/10.1016/j.ijer.2013.09.006

Cahyanti, S. D., Indriayu, M., \& Sudarmo. (2018). Implementasi Program Link and Match dengan Dunia Usaha dan Dunia Industri pada Lulusan Pemasaran SMK Negeri 1 Surakarta. BISE: Jurnal Pendidikan Bisnis Dan Ekonomo, 26(July 2018), 23-26. http://dx.doi.org/10.20961/bise.v4i1.20028

Chan, C. S. C. (2021). Helping university students discover their workplace communication needs: An eclectic and interdisciplinary approach to facilitating on-the-job learning of workplace communication. English for Specific Purposes, 64. https://doi.org/10.1016/j.esp.2021.07.002

Crawley, E. F., Hosoi, A., Long, G. L., Kassis, T., Dickson, W., \& Mitra, A. B. (2019). Moving Forward with the New Engineering Education Transformation (NEET) program at MIT - Building community, developing projects, and connecting with industry. In ASEE Annual Conference and Exposition, Conference Proceedings. https://doi.org/10.18260/1-2--33124

Crowne, K. A., Brown, M., Durant, D., Baburaj, Y., \& Hornberger, P. (2020). A program for embedding career activities in multiple core business courses. The International Journal of Management Education, 18(3). https://doi.org/10.1016/j.ijme.2020.100421

Davidescu, A. A., Apostu, S.-A., Paul, A., \& Casuneanu, I. (2020). Work Flexibility, Job Satisfaction, and Job Performance among Romanian Employees-Implications for Sustainable Human Resource Management. Sustainability, 12(15), 6086. https://doi.org/10.3390/su12156086

Disas, E. P. (2018). Link and Match sebagai Kebijakan Pendidikan Kejuruan. Jurnal Penelitian Pendidikan, 18(2), 231-242. https://doi.org/10.17509/jpp.v18i2.12965

Ferrer-Estévez, M., \& Chalmeta, R. (2021). Integrating Sustainable Development Goals in educational institutions. The International Journal of Management Education, 19(2). https://doi.org/10.1016/j.ijme.2021.100494

Gohae, A. S. (2020). Pengalaman Magang, Minat Kerja Dan Pengaruhnya Terhadap Kesiapan Kerja Mahasiswa Akuntansi. Jurnal Ilmiah MEA, 4(3), 1954-1964. https://doi.org/10.31955/mea.vol4.iss3.pp1954-1964

Hanna, B., Kee, K. F., \& Robertson, B. W. (2017). Positive Impacts of Social Media at Work: Job Satisfaction, Job Calling, and Facebook Use among Co-Workers. SHS Web of Conferences, 33(SHS Web 00012. https://doi.org/10.1051/shsconf/20173300012

Husin, Z. (2021). Outsourcing sebagai Pelanggaran atas Hak Pekerja di Indonesia. Jurnal 
Kajian Pembaruan Hukum, 1(1), 1-24. https://doi.org/10.19184/jkph.v1i1.23396

Indra, H., Waskito, \& Mulianti. (2019). Hubungan Dukungan Keluarga Dengan Minat Berwirausaha Bidang Pengelasan Pada Siswa Jurusan Teknik Mesin SMK Negeri 2 Payakumbuh. Ranah Research: Journal of Multidisciplinary Research and Development, $1(4)$, 943-949. https://jurnal.ranahresearch.com/index.php/R2J/article/view/153

Indriasari, I., \& Setyorini, N. (2018). The impact of work passion on work performance: the moderating role of P-O fit and meaningfulness of work. Diponegoro International Journal of Business, 1(1), 26. https://doi.org/10.14710/dijb.1.1.2018.26-32

Ives, R. C., Klein, K. C., \& Mason, N. A. (2020). Career and professional development services for pharmacy students. Currents in Pharmacy Teaching and Learning, 12(9). https://doi.org/10.1016/j.cpt1.2020.04.026

Khaerunnisa. (2017). Analisis Keterampilan Proses Sains (Fisika) SMA Di Kabupaten Jeneponto. Jurnal Pendidikan Fisika, 5, 340-350. https://doi.org/10.26618/jpf.v5i3.855

Liu, I.-F. (2020). The impact of extrinsic motivation, intrinsic motivation, and social selfefficacy on English competition participation intentions of pre-college learners: Differences between high school and vocational students in Taiwan. Learning and Motivation, 72. https://doi.org/10.1016/j.1mot.2020.101675

Mekler, E. D., Brühlmann, F., Tuch, A. N., \& Opwis, K. (2017). Towards understanding the effects of individual gamification elements on intrinsic motivation and performance. Computers in Human Behavior, 71, 525-534. https://doi.org/10.1016/j.chb.2015.08.048

Modebe, N. J., Okoye, L. U., \& Ado, A. (2017). Exchange rate movements and manufacturing capacity utilization in Nigeria. ESUT Journal of Accountancy, 8(1), 30-44. http://eprints.covenantuniversity.edu.ng/10195/\#.YYOW1GBBw2w

Muhtamil, M. (2017). Pengaruh Perkembangan Industri Terhadap Penyerapan Tenaga Kerja Di Provinsi Jambi. Jurnal Perspektif Pembiayaan Dan Pembangunan Daerah, 4(3), 199-206. https://doi.org/10.22437/ppd.v4i3.3642

Prabhaputra, A. A., Budiartha, I. N. P., \& Seputra, I. P. G. (2019). Sistem Outsourcing Dalam Hubungan Industrial Di Indonesia ( Outsourcing System In Industrial Relation In Indonesia). Jurnal Analogi Hukum, 1(1), 22-27. http://dx.doi.org/10.22225/wedj.2.2.1297.44-50

Purba, S. D., \& Ananta, A. N. D. (2018). The Effects Of Work Passion, Work Engagement And Job Satisfaction On Turn Over Intention Of The Millennial Generation. Jurnal Manajemen Dan Pemasaran Jasa, 263. https://doi.org/10.25105/jmpj.v11i2.2954

Putri, E. N., Ispriyarso, B., \& Cahyaningtyas, I. (2020). Optimalisasi Pengawasan Sistem Outsourcing Sebagai Upaya Menunjang Perlindungan Tenaga Kerja Di Indonesia. Notarius, 13(1), 298-311. https://doi.org/10.14710/nts.v13i1.30883

Rahmah, L., \& Muslim, S. (2019). Implementation of Competence Certification Test for the Improvement of Vocational School of Work Graduation Readiness. 1st Vocational Education International Conference, 231-237. https://doi.org/10.2991/assehr.k.191217.038

Ramdan, I. M., \& Handoko, H. N. (2016). Kecelakaan Kerja Pada Pekerja Konstruksi Informal di Kelurahan "X" Kota Samarinda. Jurnal Mkmi, 12(1), 1-6. https://journal.unhas.ac.id/index.php/mkmi/article/view/546

Rizka Pisceliya, D. M., \& Mindayani, S. (2018). Analisis Kecelakaan Kerja Pada Pekerja Pengelasan Di Cv. Cahaya Tiga Putri. Jurnal Riset Hesti Medan Akper Kesdam I/BB Medan, 3(1), 66. https://doi.org/10.34008/jurhesti.v3i1.25 
Rochmani, T. S., Purwaningsih, Y., \& Suryantoro, A. (2017). Analisis Penyerapan Tenaga Kerja Sektor Industri Di Provinsi Jawa Tengah. Jurnal Ilmu Ekonomi Dan Pembangunan, 16(2). https://doi.org/10.20961/jiep.v16i2.2322

Rybnicek, R., \& Königsgruber, R. (2019). What makes industry-university collaboration succeed? A systematic review of the literature. Journal of Business Economics, 89(2), 221-250. https://doi.org/10.1007/s11573-018-0916-6

Saefurrahman, G. U., Suryanto, T., \& Wulandari, R. E. (2017). Pengaruh penyerapan tenaga kerja terhadap pertumbuhan ekonomi pada sektor industri pengolahan. Islamic Economic Journal, 1(1), 1-18. https://doi.org/10.24042/slm.v1i1.7020

Sakthi, T., \& Moshi, A. A. M. (2021). Effectiveness measurement study on entrepreneurship awareness camp for technical education students using Kirkpatrick's model. Materials Today: Proceedings, 45(2). https://doi.org/10.1016/j.matpr.2020.08.419

Shaalan, I. E.-N. A. W. (2019). Remodeling teachers' and students' roles in self-directed learning. Journal of Language Teaching and Research, 10(3), 549-556. https://doi.org/10.17507/jltr.1003.19

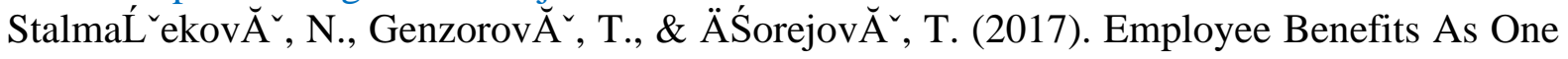
Of Factors Of Work Motivation. CBU International Conference Proceedings, 5, 448452. https://doi.org/10.12955/cbup.v5.964

Stellmacher, A., Ohlemann, S., Pfetsch, J., \& Ittel, A. (2020). Pre-service teacher career choice motivation: A comparison of vocational education and training teachers and comprehensive school teachers in Germany. International Journal for Research in Vocational Education and Training, 7(2), 214-236. https://doi.org/10.13152/ijrvet.7.2.5

Sudiarawan, K. A. (2017). Analisis Hukum Terhadap Pelaksanaan Outsourcing Dari Sisi Perusahaan Pengguna Jasa Pekerja. Jurnal Ilmu Sosial Dan Humaniora, 5(2), 835847. https://doi.org/10.23887/jish-undiksha.v5i2.9096

Sujarwanta, A., Noor, R., \& Sulistiani, W. S. (2017). Studi Ex Post Facto Pengaruh Pengalaman Saintifik Kepedulian Lingkungan Mahasiswa Pendidikan Biologi Tahun Akademik 2015 /2016. 2(1), 111-123. http://dx.doi.org/10.24127/jlplppm.v2i1.489

Sukamto. (2019). Tenaga Kerja Outsourcing Dalam Tinjauan Ekonomi Islam. Malia, 11(1), 65-80. https://doi.org/10.35891/ml.v11i1.1791

Sundar, K. \& R. V. (2019). A Study On Factors Influencing Job Preference \& Job Expectation of Gen $Z$ [Kumaraguru College of Technology]. http://dx.doi.org/10.13140/RG.2.2.19144.75528

Suttikun, C., Chang, H. J., \& Bicksler, H. (2018). A qualitative exploration of day spa therapists' work motivations and job satisfaction. Journal of Hospitality and Tourism Management, 34(5), 1-10. https://doi.org/10.1016/j.jhtm.2017.10.013

Tampu and Cochina. (2015). Motivation \& Employee Performance. Proc. Int. Manag. Proceedings of The International Management Conference, 812-821. https://econpapers.repec.org/article/rommancon/v_3a9_3ay_3a2015_3ai_3a1_3ap_3a 812-821.htm

Unuvar, O., Erbasi, A., \& Unuvar, S. (2016). Employee Satisfaction in Automotive Supply Industry: An Application in an Establishment Operating in Konya. Journal of Advanced Management Science, 4(4), 305-311. https://doi.org/10.12720/joams.4.4.305-311

Vallerand, R. J. (2015). The Psychology of Passion. In The psychology of passion: A dualistic model. Oxford University Press. https://doi.org/10.1093/acprof:oso/9780199777600.001.0001

Waruwu, M. (2020). On The Job Skill-based Servant Leadership Training Model for Principal Effectiveness. International Journal of Psychosocial Rehabilitation, 24(5), 
3270-3279. https://doi.org/10.37200/ijpr/v24i5/pr202035

Zain, I. M. (2017). The Collaborative Instructional Design System (CIDS): Visualizing the 21st Century Learning. Universal Journal of Educational Research, 5(12), 22592266. https://doi.org/10.13189/ujer.2017.051216 